\title{
Determination of Selected Volatiles in Cigarette Mainstream Smoke. The CORESTA 2009 Collaborative Study and Recommended Method*
}

\author{
by \\ Michael Intorp ${ }^{1}$, Steve W. Purkis ${ }^{2}$, and Wendy Wagstaff $^{3}$ \\ ${ }^{1}$ Imperial Tobacco Group, Albert-Einstein-Ring 7, 22761 Hamburg, Germany \\ ${ }^{2}$ Imperial Tobacco Limited, PO Box 244, Southville, Bristol BS99 7UJ, UK \\ ${ }^{3}$ Labstat International ULC, 262 Manitou Drive, Kitchener, Ontario N2C 1L3, Canada
}

\section{SUMMARY}

A recommended method has been developed and published by CORESTA, applicable to the quantification of selected volatiles (1,3-butadiene, isoprene, acrylonitrile, benzene, and toluene) in the gas phase of cigarette mainstream smoke. The method involved smoke collection in impinger traps and detection and measurement using gas chromatography/mass spectrometry techniques.

This report describes the final collaborative study applying the recommended method. It provides additional notes to inform other laboratories that might wish to adopt it, about some of the main features that need to be well controlled to provide data as robust and consistent as the data presented herein.

Data was provided by 15 industry-related and 4 independent laboratories and one governmental laboratory. Overall, 6 linear and 14 rotary smoking machines were used.

The joint experiments and collaborative work between the large number of participating laboratories has provided solutions to several methodological problems and reduced the high data variability that had initially been found particularly for 1,3-butadiene and acrylonitrile smoke yields.

Even so, the levels of reproducibility among laboratories are much greater than the levels found for 'tar', nicotine and carbon monoxide and given in the equivalent ISO standards. When expressing the reproducibility $(\mathrm{R})$ value as a percentage of the mean yield among-laboratories and across all of the studied products, values ranged from $63-93 \%$ for 1,3 -butadiene; from $36-62 \%$ for isoprene; from $41-110 \%$ for acrylonitrile; from $35-70 \%$ for benzene, and from $27-116 \%$ for toluene. For the higher 'tar' yielding products, the lower levels of variability were in line with those previously evaluated during Task Force work on standard methods for benzo $[a]$ pyrene and tobacco specific nitrosamines. As expected, the lowest 'tar' yielding product gave the most variable data. [Beitr. Tabakforsch. Int. 24 (2011) 243-251]

\section{ZUSAMMENFASSUNG}

Zur Bestimmung der ausgewählten flüchtigen organischen Verbindungen 1,3-Butadien, Isoprene, Acrylonitril, Benzol und Toluol in der Gasphase des Hauptstromrauchs von Zigaretten wurde von der CORESTA eine Methode entwickelt und veröffentlicht. Die Methode basiert auf dem Sammeln des Rauchs in Flüssigfallen und dem anschließenden Nachweis und der quantitativen Messung mittels Gaschromatographie gekoppelt mit Massenspektrometrie.

Der Report beschreibt die Studie über die Anwendung der empfohlenen Methode. Er beschreibt umfänglich für Laboratorien, die diese Methode einführen wollen, die relevanten Einflussfaktoren, die zu beachten sind, um robuste und verlässliche Daten zu erhalten.

Die Studie umfasst Daten von 15 Industrielaboratorien, 4 Auftragslaboratorien und einem staatlichen Labor. Zum Abrauchen der Zigaretten wurden 6 lineare und 14 rotative Rauchmaschinen eingesetzt.

Die Durchführung verschiedener Studien, an denen zahlreiche Laboratorien beteiligt waren, führte zur Lösung von Methodenproblemen und reduzierte die anfangs beobachteten Streuungen, insbesondere für 1,3-Butadien 
und Acrylonitril.

Dennoch sind die ermittelten Reproduzierbarkeiten zwischen den Laboratorien erheblich größer im Vergleich zu den Werten, die für Kondensat, Nikotin und Kohlenstoffmonoxid in den entsprechenden ISO Standardmethoden genannt werden. Die Reproduzierbarkeiten $(\mathrm{R})$ ausgedrückt in Prozent der Mittelwerte liegen für alle untersuchten Produkte zwischen 63-93\% bei 1,3-Butadien, $\quad 36-62 \%$ bei Isopren, $41-110 \%$ bei Acrylonitril, 35-70\% bei Benzol und 27-116\% bei Toluol. Für Produkte mit höheren Kondensatgehalten nach ISO wurden für diese Substanzen Reproduzierbarkeiten ermittelt, die vergleichbar zu denen waren, die für die Standardmethoden von Benzo[a]pyren und den tabakspezifischen Nitrosaminen berichtet wurden. Wie erwartet waren die berechneten Reproduzierbarkeiten für Produkte mit sehr niedrigen Kondensatgehalten entsprechend sehr viel höher. [Beitr. Tabakforsch. Int. 24 (2011) 243-251]

\section{RESUME}

Une méthode recommandée a été élaborée et publiée par CORESTA. Cette méthode s'applique à la quantification de substances volatiles sélectionnées (1,3-butadiène, isoprène, acrylonitrile, benzène, et toluène) lors de la phase gazeuse de la fumée principale de cigarette. La méthode a associé le captage de la fumée dans des pièges à impact, la détection et la quantification en utilisant les techniques de la chromatographie en phase gazeuse et la spectrométrie de masse.

Ce rapport décrit l'étude collective finale appliquant la méthode recommandée. Il fournit des notes supplémentaires pour informer d'autres laboratoires qui souhaiteraient adopter cette méthode des principales caractéristiques devant être bien contrôlés pour fournir des données qui soient aussi solides et cohérentes que les données présentées ci-dessous.

Les données ont été fournies par 15 laboratoires liés à l'industrie et 4 laboratoires indépendants et un laboratoire gouvernemental. Au total, 6 machines à fumer linéaires et 14 machines à fumer rotatives ont été employées.

Les expériences communes et le travail collectif d'un nombre important de laboratoires participants ont résolu de nombreux problèmes méthodologiques et réduit la variabilité élevée entre les données qui avait été constatées dans un premier temps en particulier pour les teneurs en butadiène et en acrylonitrile dans la fumée.

Les niveaux de reproductibilité parmi les laboratoires restent quand même nettement supérieurs aux taux constatés et indiqués dans les normes ISO équivalentes pour le goudron, la nicotine et le monoxyde de carbone. Lorsque la valeur de la reproductibilité (R) est exprimée en pourcentage de la teneur moyenne entre les laboratoires sur l'ensemble des produits étudiés, les valeurs variaient de 63 à $93 \%$ pour le 1,3 -butadiène; de 36 à $62 \%$ pour l'isoprène; de 41 à $110 \%$ pour l'acrylonitrile; de 35 à $70 \%$ pour le benzène et de 27 à $116 \%$ pour le toluène. Pour les produits à teneur plus forte en goudron, les niveaux inférieurs de variabilité étaient cohérents avec ceux préalablement évalués pendant les travaux du groupe d'étude sur les méthodes standard pour le benzo $[a]$ pyrène et les nitrosami- nes spécifiques au tabac. Comme on s'y attendait, le produit ayant la plus faible teneur en goudron a donné les résultats les plus variables. [Beitr. Tabakforsch. Int. 24 (2011) 243-251]

\section{PARTICIPATING LABORATORIES}

A summary of the twenty participating laboratories and their principal investigators is given below. The Task Force co-ordinators wish to acknowledge the contributions of each principal investigator and their colleagues without whom the work of the Task Force could not have been completed.

\begin{tabular}{|c|c|}
\hline $\begin{array}{l}\text { Participating laboratories and } \\
\text { institutions }\end{array}$ & Principal investigators \\
\hline Arista (USA) & $\begin{array}{l}\text { Brad Norwood / } \\
\text { Fraser Williamson }\end{array}$ \\
\hline Arista Labs Europe (UK) & Tatiana Humphries \\
\hline BAT - Souza Cruz (Brazil) & Waldenir Farias Braga \\
\hline British American Tobacco (UK) & Tina Mead \\
\hline CNTC Beijing (China) & Jun Zhou \\
\hline CNTC QSTC (China) & Hongwei Hou \\
\hline CNTC ZTRI (China) & Fuwei Xie \\
\hline $\begin{array}{l}\text { Chemisches und Veterinär- } \\
\text { landesuntersuchungsamt } \\
\text { Sigmaringen (Germany) }\end{array}$ & Jürgen Hahn \\
\hline Filtrona International (UK) & Mike Taylor \\
\hline $\begin{array}{l}\text { Imperial Tobacco Group / } \\
\text { ALTADIS (France) }\end{array}$ & Sandrine Destruhaut \\
\hline $\begin{array}{l}\text { Imperial Tobacco Group / } \\
\text { Reemtsma (Germany) }\end{array}$ & Michael Intorp / Steve Purkis \\
\hline Japan Tobacco (Japan) & Takatsugu Hyodo \\
\hline $\begin{array}{l}\text { Japan Tobacco International } \\
\text { (Austria) }\end{array}$ & Jutta Pani \\
\hline KT\&G (Korea) & Hyo-Keun Kim \\
\hline Labstat (Canada) & Pete Joza / Wendy Wagstaff \\
\hline Lorillard (USA) & Rob Stevens \\
\hline $\begin{array}{l}\text { Philip Morris Research } \\
\text { Laboratories (Germany) }\end{array}$ & Jörg Diekmann \\
\hline $\begin{array}{l}\text { Philip Morris International } \\
\text { (Switzerland) }\end{array}$ & Michel Rotach \\
\hline $\begin{array}{l}\text { Philip Morris Sampoerna } \\
\text { (Indonesia) }\end{array}$ & $\begin{array}{l}\text { Bimo Haryo Progo / } \\
\text { Rachmat Hidayat }\end{array}$ \\
\hline $\begin{array}{l}\text { Rothmans Benson and Hedges } \\
\text { (Canada) }\end{array}$ & $\begin{array}{l}\text { Jennifer DeGraaf / } \\
\text { lan Jenkins }\end{array}$ \\
\hline
\end{tabular}

The Task Force co-ordinators also wish to acknowledge the contributions made by other Task Force members, William M. Coleman III (R.J. Reynolds, USA), Linda Crumpler (Cerulean, USA), and Katrin Schade (Borgwaldt, Germany).

\section{INTRODUCTION}

A CORESTA study carried out in 2006 (1) described an investigation of some of the main parameters that may cause variability in smoke analyte yields collected from both the particulate and gas phase of mainstream cigarette smoke when machine smoking under ISO conditions (2). The laboratories had used their own in-house methods to 
determine yields and the work had been carried out to obtain guidance towards a robust and practicable recommended method.

Initial work was followed by exploratory joint experiments on the best and necessary features that need to be incorporated in a recommended method. The Part 1 report (3) on the selected smoke volatiles (1,3-butadiene, benzene, toluene, isoprene, and acrylonitrile) had shown that similar yields were obtained when comparing data from Tedlar bag trapping with those from impinger traps, the latter method being used by the majority of laboratories. Several key parts of the methodology were investigated in detail to evaluate their effects on smoke yields and the learning exercise proved to be a further important directional step towards a recommended method.

The work described in this report provides details on a CORESTA collaborative study leading to a recommended method (4), and based on the Health Canada method (5) for the determination of selected volatiles in the gas phase of cigarette mainstream smoke. The statistical analysis of the yield data from 20 laboratories including repeatability and reproducibility data is also presented. The report describes key components of the recommended method and provides additional notes to inform other laboratories about some of the main features that need to be well controlled to provide data as robust and consistent as the data presented herein.

\section{EXPERIMENTAL}

\section{Recommended method}

A CORESTA recommended method (CRM 70) (4) was agreed upon by the Special Analytes Task Force based on the learning from the earlier joint experiment (3).

After conditioning (6), cigarettes were smoked under standardised conditions (2). The smoking machine was additionally equipped with impinger traps containing methanol cryogenically cooled to $-70{ }^{\circ} \mathrm{C}$ into which the gas phase components of cigarette mainstream smoke were trapped and collected, as shown, for example, in Figure 1. The impinger solutions were spiked with hexa-deuterated benzene standard; an aliquot of the solution was separated on a gas chromatograph and the selected volatiles (1,3butadiene, benzene, toluene, acrylonitrile, and isoprene) were detected and quantified by mass spectrometry by the single ion monitoring (SIM) technique using the ions specified in CRM 70.

It should be noted that the minimal yields of selected volatiles that trap within the particulate phase on the Cambridge filter pad are not included in these measurements. An example chromatogram for the 3R4F Kentucky Reference cigarette is given in Figure 2. No internal standard is shown in the chromatogram.

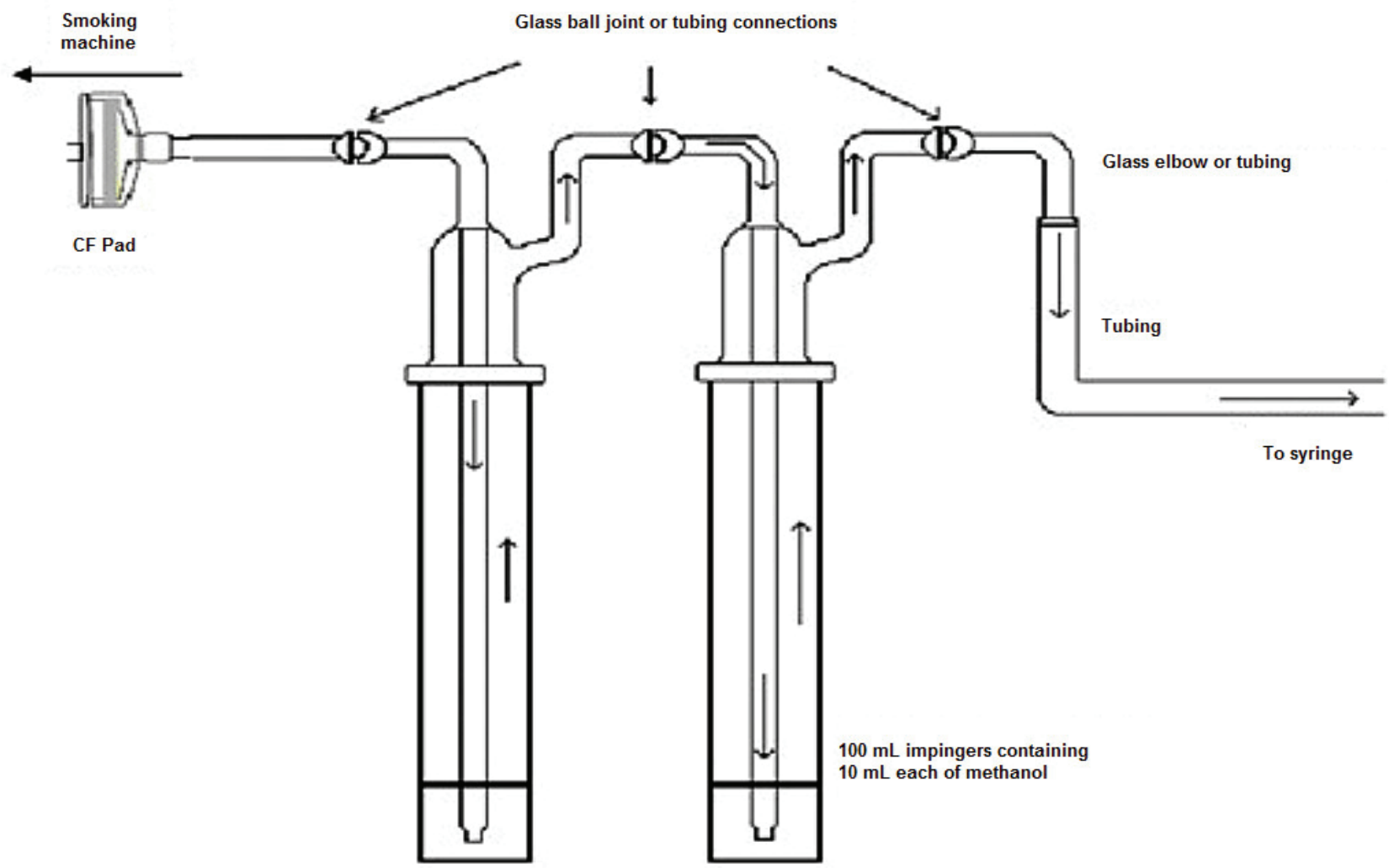

Figure 1. Example of an impinger setup for smoking machines. 


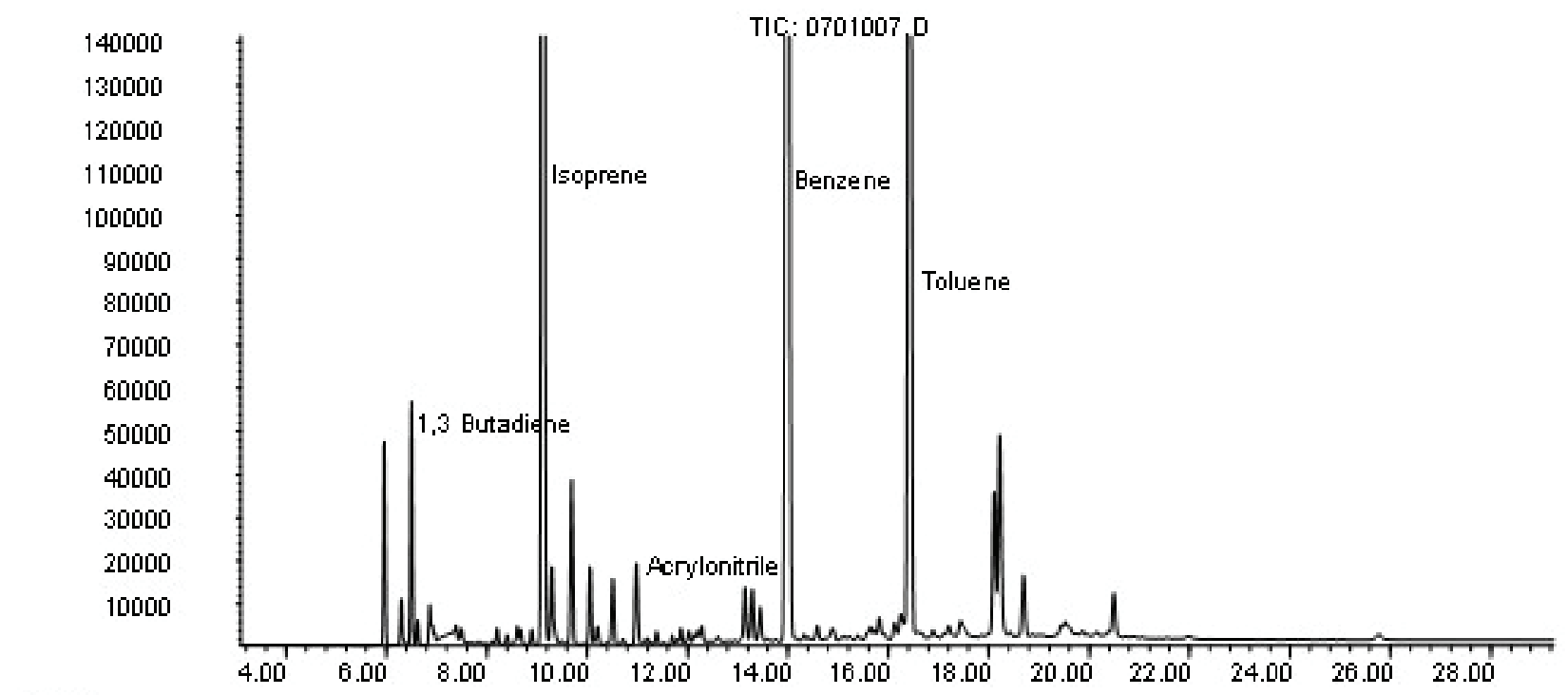

Time-->

Figure 2. Example chromatogram for the 3R4F Kentucky Reference cigarette.

\section{OVERVIEW OF THE PROTOCOL AND SAMPLE DESCRIPTIONS}

The main objective of the collaborative study was to run the recommended method for the determination of selected volatiles (1,3-butadiene, benzene, toluene, acrylonitrile, and isoprene) in the gas phase of cigarette mainstream smoke to provide robust repeatability and reproducibility data.

The test samples listed in Table 1 were used in the collaborative study. Samples 1-5 were commercially available cigarettes provided by various manufacturers to represent a range of 'tar' yields, blend and cigarette design styles to complement the three reference cigarettes (CM6, $1 \mathrm{R} 5 \mathrm{~F}$, and $3 \mathrm{R} 4 \mathrm{~F}$ ).

Table 1. Cigarette test samples.

\begin{tabular}{llc}
\hline $\begin{array}{l}\text { Sample } \\
\text { code }\end{array}$ & \multicolumn{1}{c|}{ Blend and design } & $\begin{array}{c}\text { NFDPM yield } \\
(\mathrm{mg})\end{array}$ \\
\hline Sample 1 & Dark air cured blend / CA filter & 10 \\
Sample 2 & American blend / CA filter & 6 \\
Sample 3 & Virginia blend / CA filter & 8 \\
Sample 4 & American blend / charcoal filter & 1 \\
Sample 5 & American blend / charcoal filter & 10 \\
CM6 & CORESTA monitor / & 15 \\
& Virginia blend / CA filter \\
1R5F & Kentucky reference / & American blend / CA filter \\
3R4F & Kentucky rtference / & 2 \\
& American blend / CA filter & 8 \\
\hline
\end{tabular}

The laboratories were asked to smoke the five replicates of the eight test samples using a randomized design within eight runs per experiment. In this way, each replicate was part of a separate experiment as shown in the smoking plan given in Table 2.

Table 2. Smoking plan.

\begin{tabular}{l|cccccc}
\hline \multirow{2}{*}{$\begin{array}{l}\text { Run } \\
\text { No. }\end{array}$} & \multicolumn{5}{|c}{ Experiment number } \\
\cline { 2 - 6 } & 1 & 2 & 3 & 4 & 5 \\
\hline 1 & CM6 & Sample 5 & Sample 3 & CM6 & 3R4F \\
2 & Sample 4 & Sample 1 & Sample 5 & Sample 2 & Sample 4 \\
3 & Sample 1 & 1R5F & Sample 1 & 1R5F & Sample 5 \\
4 & Sample 2 & CM6 & CM6 & Sample 3 & Sample 2 \\
5 & Sample 5 & Sample 2 & Sample 4 & Sample 5 & 1R5F \\
6 & 3R4F & Sample 3 & Sample 2 & 3R4F & Sample 3 \\
7 & 1R5F & 3R4F & 3R4F & Sample 1 & CM6 \\
8 & Sample 3 & Sample 4 & 1R5F & Sample 4 & Sample 1 \\
\hline
\end{tabular}

\section{RESULTS}

Analytical yields of the five selected volatiles were obtained and mean yields are given in Table 3 (calculated after exclusion of outliers as described later). Each laboratory recorded the dates on which the analyses were performed and most laboratories provided information on the limits of detection (LOD) and limits of quantification (LOQ), with the range summarized as maximum and minimum values in Table 4 . There was no requirement that LOQs or LODs were measured in the same way at different laboratories and this is reflected in the wide range given in Table 4.

However, there was no indication that the means of determining LODs / LOQs lead to lower or higher levels of outlier or excluded data. Excellent recovery rates were given by all laboratories for the selected volatiles as shown in Table 5. 
Table 4. Limits of quantification (LOQ) and limits of detection (LOD).

\begin{tabular}{|c|c|c|c|c|c|c|}
\hline & $\mu \mathrm{g} / \mathrm{cig}$ & 1,3-Butadiene & Benzene & Toluene & Acrylonitrile & Isoprene \\
\hline \multirow{2}{*}{ LOQ } & minimum & 0.08 & 0.02 & 0.04 & 0.03 & 0.05 \\
\hline & maximum & 7.44 & 4.63 & 8.32 & 3.97 & 31.8 \\
\hline \multirow{2}{*}{ LOD } & minimum & 0.03 & 0.01 & 0.01 & 0.01 & 0.02 \\
\hline & maximum & 2.22 & 1.39 & 2.50 & 1.32 & 9.6 \\
\hline \multirow{2}{*}{ Recovery } & minimum & 89 & 90 & 95 & 85 & 91 \\
\hline & maximum & 109 & 109 & 111 & 112 & 110 \\
\hline
\end{tabular}

\section{DATA ANALYSIS}

\section{Variability of standard smoke parameters}

Total Particulate Matter (TPM) and puff count data were calculated (7) as received from all participating laboratories and are summarised in Table 5. The low puff count variability indicated good adherence to the ISO conditioning standard (6) by the participating laboratories. The highest variability in TPM yields was associated with the lowest yielding cigarette types, i.e. 1R5F and Sample 4.

Table 5. TPM and puff count data.

\begin{tabular}{l|c|r|r|r}
\hline \multirow{2}{*}{ Sample code } & \multicolumn{2}{|c|}{ Puffs } & \multicolumn{2}{c}{ TPM } \\
\cline { 2 - 5 } & Mean & CoV\% & Mean & CoV\% \\
\hline \multirow{2}{*}{ CM6 } & 9.3 & 3.5 & 18.3 & 5.7 \\
1R5F & 6.9 & 2.7 & 2.5 & 13.8 \\
3R4F & 8.4 & 2.7 & 10.7 & 6.6 \\
Sample 1 & 5.7 & 3.4 & 12.9 & 12.6 \\
Sample 2 & 9.8 & 4.1 & 6.9 & 12.3 \\
Sample 3 & 6.9 & 3.4 & 12.3 & 8.1 \\
Sample 4 & 6.8 & 5.6 & 1.7 & 14.9 \\
Sample 5 & 7.4 & 3.6 & 13.8 & 7.0 \\
\hline
\end{tabular}

Where CoV = Coefficient of Variation
Table 6 shows the effect on volatile yields of the two different smoking machine types used in the laboratories. Six laboratories used "linear" and 14 used "rotary" smoking machines for smoke collection. No observable effect of smoking machine type was found for any of the studied analytes although this was not statistically tested.

\section{General statistical analysis}

Statistical calculations were based on ISO guidelines $(8,9)$ and applied directly to determine estimates of repeatability (r) and reproducibility (R) after smoking under defined conditions (2), where all of the participating laboratories used the same analytical method (4).

Determination of inter-laboratory repeatability and reproducibility variance

For each of the $j$ test samples $(j=1, \ldots, 8)$, the general mean $\left(\overline{\bar{y}}_{j}\right)$ was determined according to ISO 5725-2 section 7.4.4 (8) over the $p$ participating laboratories, whose data remained following the removal of outliers. The outlier analysis methods are discussed in the following sections.

Table 6. Effect of smoking machine type on selected volatile yields.

\begin{tabular}{|c|c|c|c|c|c|c|}
\hline Sample & Smoking machine & $\begin{array}{c}\text { 1,3-Butadiene } \\
(\mu \mathrm{g} / \mathrm{cig})\end{array}$ & $\begin{array}{c}\text { Benzene } \\
(\mu \mathrm{g} / \mathrm{cig})\end{array}$ & $\begin{array}{l}\text { Toluene } \\
(\mu \mathrm{g} / \mathrm{cig})\end{array}$ & $\begin{array}{c}\text { Acrylonitrile } \\
(\mu \mathrm{g} / \mathrm{cig})\end{array}$ & $\begin{array}{c}\text { Isoprene } \\
\text { ( } \mu \text { g/cig) }\end{array}$ \\
\hline \multirow{2}{*}{ CM6 } & linear & 61.6 & 59.7 & 88.6 & 12.0 & 570 \\
\hline & rotary & 59.6 & 60.5 & 84.0 & 12.5 & 546 \\
\hline \multirow{2}{*}{ 1R5F } & linear & 11.9 & 13.1 & 15.7 & 2.0 & 116 \\
\hline & rotary & 12.4 & 14.8 & 19.5 & 2.2 & 122 \\
\hline \multirow{2}{*}{ 3R4F } & linear & 38.8 & 39.9 & 64.4 & 8.4 & 355 \\
\hline & rotary & 42.5 & 42.7 & 64.9 & 8.6 & 365 \\
\hline \multirow{2}{*}{ Sample 1} & linear & 31.4 & 37.1 & 57.6 & 10.0 & 206 \\
\hline & rotary & 32.5 & 39.3 & 57.9 & 10.4 & 221 \\
\hline \multirow{2}{*}{ Sample 2} & linear & 30.3 & 30.2 & 44.7 & 5.1 & 255 \\
\hline & rotary & 31.3 & 32.2 & 44.3 & 5.4 & 256 \\
\hline \multirow{2}{*}{ Sample 3} & linear & 31.7 & 33.4 & 49.0 & 7.4 & 243 \\
\hline & rotary & 32.9 & 35.5 & 49.3 & 7.5 & 247 \\
\hline \multirow{2}{*}{ Sample 4} & linear & 7.1 & 6.1 & 5.9 & 0.8 & 57 \\
\hline & rotary & 7.3 & 7.4 & 9.7 & 1.1 & 59 \\
\hline \multirow{2}{*}{ Sample 5} & linear & 37.9 & 27.7 & 37.5 & 6.3 & 276 \\
\hline & rotary & 39.5 & 28.8 & 37.4 & 6.4 & 283 \\
\hline
\end{tabular}


Determination of inter-laboratory repeatability and reproducibility variance

For each of the $j$ test samples $(j=1, \ldots, 8)$, the general mean $\left(\overline{\bar{y}}_{j}\right)$ was determined according to ISO 5725-2 section 7.4.4 (8) over the $p$ participating laboratories, whose data remained following the removal of outliers. The outlier analysis methods are discussed in the following sections.

General mean $=\left(\overline{\overline{\mathrm{y}}}_{j}\right)=\frac{\sum_{i=1}^{p} n_{i j} \overline{\mathrm{y}}_{i j}}{\sum_{i=1}^{p} n_{i j}}$

where $\overline{\mathrm{y}}_{i j}$ is the mean for test sample $j$ as reported by laboratory $i$ and $n_{i j}$ is the number of observations.

Repeatability variance $\left(s_{r j}^{2}\right)$ was determined as per ISO 5725-2 section 7.4.5.1 (9).

Repeatability variance $s_{r j}^{2}=\frac{\sum_{i=1}^{p}\left(n_{i j}-1\right) s_{i}^{2}}{\sum_{i=1}^{p}\left(n_{i j}-1\right)}$

where $s_{r j}^{2}$ is the within-laboratory variance for test sample $j$ as reported by laboratory $i$.

Reproducibility variance $\left(s_{R j}^{2}\right)$ was determined as per ISO 5725-2 section 7.4.5.5 (9).

Reproducibility variance $s_{R j}^{2}=s_{r j}^{2}+s_{L j}^{2}$ where $s_{L j}^{2}$ is the between-laboratory variance and calculated as

$$
s_{L j}^{2}=\frac{\left(\frac{\sum_{i=1}^{p} n_{i j}\left(\overline{\mathrm{y}}_{i j}-\overline{\overline{\mathrm{y}}}_{j}\right)^{2}}{p-1}\right)-s_{r j}^{2}}{\sum_{i=1}^{p} n_{i j}-\left(\frac{\sum_{i=1}^{p}\left(n_{i j}\right)^{2}}{\sum_{i=1}^{p} n_{i j}}\right)}
$$

Data excluded due to being below the limits of quantification

Some individual data points were reported as non-numeric (i.e. below the LOQ) and had to be removed prior to evaluation of numeric data for outliers. This applied particularly to 1,3-butadiene and acrylonitrile. For 1,3butadiene, 759 of the possible 800 observations and for acrylonitrile, 768 of the possible 800 observations were above the LOQ. A summary of exclusions is given in Table 7.

Data excluded within the context of among-laboratory variability $(R)$

For evaluation of agreement among laboratories, the Grubbs' test was applied as described (8) to detect single or multiple outlying laboratories with respect to the sample mean.

If the Grubbs statistic was significant at the 5\% level, the sample data from that laboratory was removed. Six out of eight samples had significant Grubbs results (at 1\%) for high outliers for acrylonitrile data from laboratory 18 . Hence, all eight test samples were excluded from the analysis due to the expectation that there was a problem with the entire acrylonitrile analysis for this laboratory.

The Grubbs statistic for a single high outlier was significant for the following analytes, samples and laboratories. The data, as shown in Table 8, was removed prior to the calculations of the general mean, repeatability and reproducibility variance.

- 1,3-butadiene: laboratory 18 (Sample 3 and CM6)

- Isoprene: laboratory 13 (Sample 4)

- Benzene: laboratory 13 (Sample 4)

- Acrylonitrile: laboratory 18 (Samples 1, 2, 3, 4, 5, and CM6, 1R5F, 3R4F).

Data excluded within the context of within-laboratory variability $(r)$

The approach used was to consider of highest importance the removal of data from those laboratories whose means were not in agreement with other laboratories. The degree of agreement for within-laboratory variance was not evaluated with as much rigour as the among-laboratory variance. In this case, only those laboratories whose variation among five replicates was considered 'abnormally high' in comparison to the other laboratories, that is, with a standard deviation at least two times greater than that reported for any other laboratory, were examined for potential outliers. The determination of the outliers was made based on a comparison with the individual values reported by the other laboratories. In this way some data from laboratory 16 were excluded and are shown in Table 8.

Table 7. Excluded data below LOQ.

\begin{tabular}{|c|c|c|c|c|}
\hline Laboratory & Sample 2 & Sample 4 & 1R5F & All samples \\
\hline 4 & & all acrylonitrile data & & \\
\hline 8 & & all acrylonitrile data & $\begin{array}{l}\text { acrylonitrile data for single } 1 \mathrm{R} 5 \mathrm{~F} \\
\text { data point }\end{array}$ & \\
\hline 12 & all acrylonitrile data & all acrylonitrile data & $\begin{array}{l}\text { all acrylonitrile data } \\
\text { butadiene data for single } 1 \mathrm{R} 5 \mathrm{~F} \\
\text { data point }\end{array}$ & \\
\hline 19 & & all acrylonitrile data & $\begin{array}{l}\text { acrylonitrile data for single } 1 \mathrm{R} 5 \mathrm{~F} \\
\text { data point }\end{array}$ & $\begin{array}{l}\text { all butadiene data although } \\
\text { LOQ not supplied }\end{array}$ \\
\hline
\end{tabular}


Table 8. Data exclusion after statistical evaluation.

\begin{tabular}{|c|c|c|}
\hline Analyte & $\mathrm{Lab}$ & $\begin{array}{l}\text { Outlier types for excluded laboratory } \\
\text { data }\end{array}$ \\
\hline \multirow[t]{2}{*}{$\begin{array}{l}\text { 1,3- } \\
\text { Butadiene }\end{array}$} & 18 & $\begin{array}{l}\text { Mean and variance outliers for } \\
\text { sample } 3 \text { and CM } 6\end{array}$ \\
\hline & 13 & Mean outliers for sample 4 \\
\hline Benzene & 16 & $\begin{array}{l}\text { Variance outlier for single } \\
\text { replicate in } 1 \mathrm{R} 5 \mathrm{~F}\end{array}$ \\
\hline \multirow[t]{2}{*}{ Toluene } & 16 & Variance outliers for $1 \mathrm{R} 5 \mathrm{~F}$ \\
\hline & 16 & Variance outliers for 2 low 1R5F \\
\hline \multirow[t]{2}{*}{ Acrylonitrile } & 18 & replicates \\
\hline & 13 & $\begin{array}{l}\text { Mean outliers for all samples } \\
\text { Mean outliers for sample } 4\end{array}$ \\
\hline
\end{tabular}

\section{Summary of excluded data}

A summary of the number of observations made and the number of observations excluded as outliers is given in Table 9. The results show that a very small percentage of observations were treated as outliers $(0.6-5.5 \%)$ for each analyte.

Table 9. Overall summary of excluded data

\begin{tabular}{l|c|c|c|c}
\hline \multirow{2}{*}{ Analyte } & \multicolumn{4}{|c}{ Outlier summary } \\
\cline { 2 - 6 } & $\begin{array}{c}\text { Total number } \\
\text { of } \\
\text { observations }\end{array}$ & $\begin{array}{c}\text { Total } \\
\text { reported } \\
\text { observations } \\
(\%)\end{array}$ & $\begin{array}{c}\text { Number of } \\
\text { excluded } \\
\text { observations }\end{array}$ & $\begin{array}{c}\text { Outliers } \\
(\%)\end{array}$ \\
\hline $\begin{array}{l}\text { 1,3- } \\
\text { Butadiene }\end{array}$ & 759 & 94.9 & 10 & 1.3 \\
$\begin{array}{l}\text { Benzene } \\
\text { Toluene }\end{array}$ & 800 & 100 & 10 & 1.3 \\
Acrylonitrile & 700 & 100 & 5 & 0.6 \\
Isoprene & 768 & 96.0 & 42 & 5.5 \\
\hline
\end{tabular}

After exclusion of outlier data, the mean smoke yields and levels of repeatability and reproducibility of 1,3-butadiene, toluene, benzene acrylonitrile, and isoprene across each of the cigarette types were summarized in Table 3 . The levels of variability found for the $3 \mathrm{R} 4 \mathrm{~F}$ and $1 \mathrm{R} 5 \mathrm{~F}$ products were improved when compared to previous studies, where laboratories either used their preferred methodology (1) or similar methods in joint experiment work (3).

However, the levels of reproducibility among laboratories are still much worse than the levels found for 'tar', nicotine, and carbon monoxide and given ISO 8243 (10). When expressing the $\mathrm{R}$ value as a percentage of the mean across all of the studied products, values ranged from $63-93 \%$ for 1,3-butadiene; from $36-62 \%$ for isoprene; from $41-110 \%$ for acrylonitrile; from $35-70 \%$ for benzene, and from $27-116 \%$ for toluene. For the higher 'tar' yielding products the levels of variability were in line with those previously evaluated during work on CRMs for benzo[a]pyrene (11) and tobacco-specific nitrosamines (12). The lowest 'tar' yielding product (Sample 4) gave the most variable data.

\section{Some recommendations on the methodology}

The knowledge gained from the joint experiments and the practical experience shared within the Task Force has led to the following recommendations.

\section{Tubing}

Figure 1 shows glass tubing as being mainly used to connect the smoking machine to the impingers. However, tubing other than silicone can also be used, such as polyethylene, polypropylene, or polyvinyl chloride (e.g. Tygon). Adsorption of the analytes on to silicon tubing has been found to occur and its use is not recommended. Tubing should be as short as possible between connections to minimise the potential for any adsorption.

\section{Trapping efficiency}

It is recommended that the trapping efficiency should be checked when validating this method. A third impinger should be added to check the trapping efficiency and the method followed accordingly. Each impinger should be analysed individually for the volatile compounds of interest. If no compounds are detected in the third impinger then only two impingers are required to trap all the volatiles effectively.

\section{Minimisation of 1,3-butadiene variability}

Variability could be reduced by storage in a cooled autosampler, by thorough closure of and minimisation of headspace in the vial. A UV method (5) is recommended to measure 1,3-butadiene yields in stock solution.

\section{Minimisation of acrylonitrile variability}

A broad chromatographic peak is often found for this analyte due to combination of its low level and the choice of chromatographic stationary phase. Individual laboratories need to find their optimum conditions during their validation procedures.

\section{Internal standards}

Individual laboratories may not choose to use deuterated benzene-d6 as an internal standard (IS) and, for example, may wish to apply deuterated toluene-d5. However, the collaborative study for the CRM used benzene-d6 and the $\mathrm{r}$ and $\mathrm{R}$ values were based on this IS. Therefore, any laboratory that wishes to modify the calibration will need to carry out proper validation with the different IS.

If there are commercially available calibration solutions then these can be used instead of preparation of fresh IS. Certified standards should be checked to ensure that they are of the correct concentration. All solutions should be checked for stability before use and the effect of local storage conditions. IS concentrations should be used that are within the range of the expected yields of the studied products. 


\section{CONCLUSIONS}

The CORESTA Special Analytes Task Force has developed a CRM identifying and optimizing key components of the methodology that contribute significantly to variability of test results.

The relative levels of reproducibility among laboratories are much higher than the levels found for 'tar', nicotine and carbon monoxide given in ISO 4387 (7). When expressing the ' $R$ ' value as a percentage of the mean across all of the studied products, values ranged from $63-93 \%$ for $1,3-$ butadiene; from $36-62 \%$ for isoprene; from $41-110 \%$ for acrylonitrile; from $35-70 \%$ for benzene, and from $27-116 \%$ for toluene. For the higher 'tar' yielding products the levels of variability were in line with those previously evaluated during work on standard methods for benzo $[a]$ pyrene and tobacco-specific nitrosamines. The lowest 'tar' yielding product (Sample 4) gave the most variable data.

\section{REFERENCES}

1. Intorp, M., S.W. Purkis, M.W. Whittaker, and W. Wright: Determination of "Hoffmann Analytes" in Cigarette Mainstream Smoke. The CORESTA 2006 Joint Experiment; Beitr. Tabakforsch. Int. 23 (2009) 161-202.

2. ISO, International Organization for Standardization: ISO 3308, Routine Analytical Cigarette-Smoking Machine - Definitions and Standard Conditions; Geneva, 2000.

3. Intorp M. and S.W. Purkis: Determination of Selected Volatiles in Cigarette Mainstream Smoke. The CORESTA 2008 Joint Experiment; Beitr. Tabakforsch. Int. 24 (2011) 174-186.

4. CORESTA Recommended Method 70: Determination of Selected Volatile Organic Compounds in the Mainstream Smoke of Cigarettes - Gas Chromatography - Mass Spectrometry Method; (2010) http://www.coresta.org/Recommended_Methods/CR M_70.pdf (Accessed October 2010).

5. Health Canada Method: Determination of 1,3Butadiene, Isoprene, Acrylonitrile, Benzene, and Toluene in Mainstream Tobacco Smoke 1999; http://www.hc-sc.gc.ca/hc-ps/alt_formats/hecssesc/pdf/tobac-tabac/legislation/reg/indust/ method/_main-principal/isopren-eng.pdf (Accessed December 2010).

6. ISO, International Organization for Standardization: ISO 3402, Tobacco and Tobacco Products - Atmosphere for Conditioning and Testing; Geneva, 1999.

7. ISO, International Organization for Standardization: ISO 4387, Cigarettes - Determination of Total and Nicotine-Free Dry Particulate Matter Using a Routine Analytical Smoking Machine; Geneva, 2000.

8. ISO, International Organization for Standardization: ISO 5725-1, Accuracy (Trueness and Precision) of Measurement Methods and Results - Part 1: General Principles and Definitions; Geneva, 1994.

9. ISO, International Organization for Standardization: ISO 5725-2, Accuracy (Trueness and Precision) of Measurement Methods and Results - Part 2: Basic Method for the Determination of Repeatability (r) and Reproducibility (R) of a Standard Measurement Method; Geneva, 1994.

10. ISO, International Organization for Standardization: ISO 8243, Cigarettes - Sampling; Geneva, 2006.

11. CORESTA Recommended Method 58: Determination of Benzo $[a]$ pyrene in Cigarette Mainstream Smoke Gas Chromatography - Mass Spectrometry Method; (2004)

http://www.coresta.org/Recommended_Methods/CR M_58.pdf (Accessed October 2010).

12. CORESTA Recommended Method 63: Determination of Tobacco-Specific Nitrosamines in Cigarette Mainstream Smoke - GC-TEA method; (2005). http://www.coresta.org/Recommended_Methods/ CRM_63.pdf (Accessed October 2010).

Corresponding author:

Steve W. Purkis

Imperial Tobacco Limited

PO Box 244, Southville

Bristol BS99 $7 U J$

$U K$

E-mail: Steve.Purkis@uk.imptob.com 


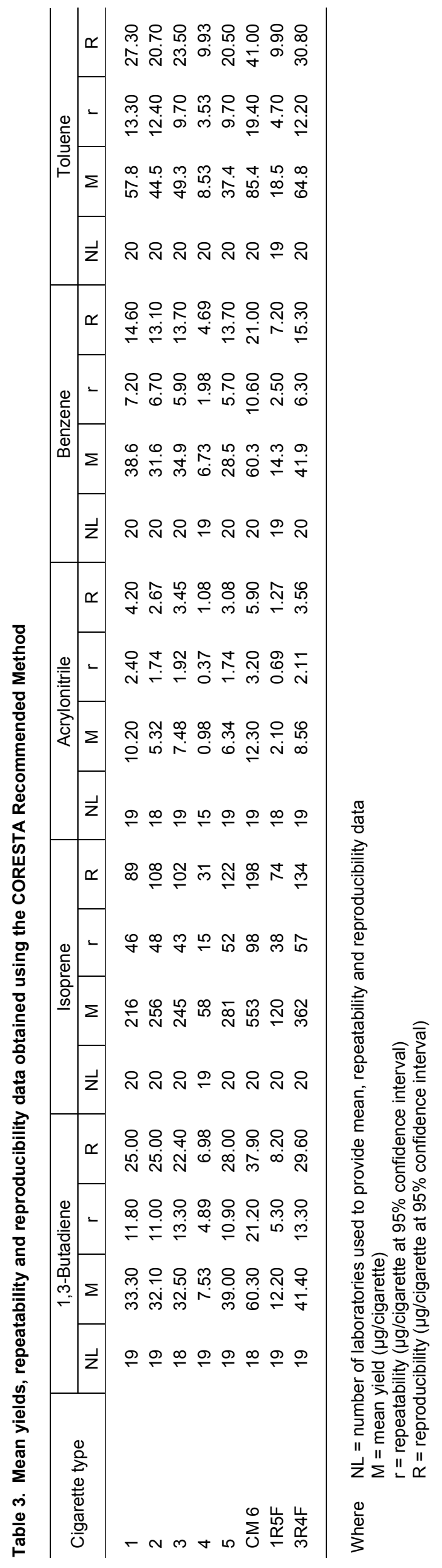

